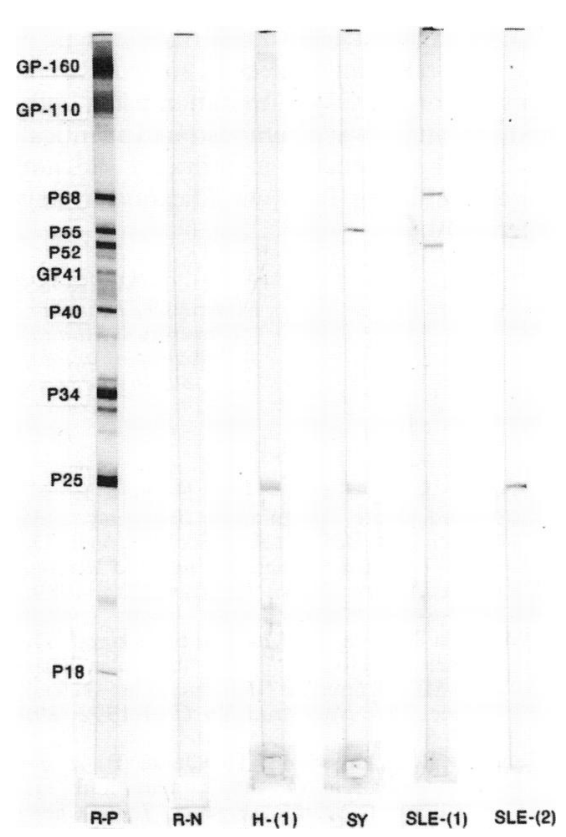

Typical Western blotting pattern of human immunodeficiency virus type 1 (HIV-1) antibody of controls and patients [R-P; reference serum positive for anti-HIV-1 antibody, R-N; reference serum negative for anti-HIV-1 antibody, $\mathrm{H}-(1)$; healthy control positive for anti-P25 antibody, SY; syphilis patient $(S-6)$ positive for anti-P25 and anti-P55 antibodies, $S L E-(1)$; SLE patient ( $L A / a C L$ negative) (N-9) positive for anti-P52 and anti-P68 antibodies, SLE-(2); SLE patient with aCL $(C-2)$, positive for anti-P25 and anti-P52 antibodies].

and 4/23 (17\%) aCL/LA-negative]. None of the subjects' sera that was reactive to HIV-1 and/or HTLV-1 viral proteins showed a typical reactive pattern diagnostic of true HIV-1 and/or HTLV-1.

Talal et $a l^{1}$ reported that $22 / 61$ patients with SLE were positive for p24 (synonymous with p25 in this paper) antibody and suggested that there was a close relation between HIV-1 and conserved idiotype antibody. They also found that anti-Sm antibody in this clinical setting showed cross-reaction with p24. Blick et $a l^{2}$ confirmed that HIV-1 hybridising sequences are frequently present in patients with SLE. Furthermore, Ranki et al reported that a few patients with connective tissue diseases, including SLE, had antibodies reactive to the gag protein (p24, p55) of HIV-1.

These reports prompted us to investigate whether or not there was a connection between the prevalence of $\mathrm{aCL}$ and/or LA and retrovirus infection in patients with SLE. Contrary to our hypothesis, however, the HIV-1 antibodies were more frequently detected in aCL/LA-negative SLE patients than in aCL/LA-positive SLE patients. These findings indicated that there may be pathogens and/or factors other than retroviruses acting in the aetiology of $S_{L E}{ }^{10}$ along with aCL/LA production, and this point needs to be clarified further.

JUZO MATSUDA MORITAKA GOTOH KENGO GOHCHI KIYO TSUKAMOTO NORIKO SAITOH NORIKO SAITOH
Department of Medicine, Teikyo University,
School of Medicite, School of Medicine, Tokyo, Fapan
Correspondence to: Dr J Matsuda, Department of Medicine, Teikyo University School of Medicine 11-1, Kaga 2-Chrome, Itabashi-Ku, Tokyo 173, Japan.

1 Talal N, Garry J R F, Schur P H, et al. A conserved idiotype and antibodies to retroviral proteins in systemic lupus erythematosus. f Clin Invest 1990; 85: 1866-71.

2 Blick M, Bresser J, Lepe-Zuniga J L, et al. Identification of human immunodeficiency virus hybridizing sequences in the peripheral blood of a patient with systemic lupus erythematosus. F Am Acad Dermatol 1990; 23: 641-5.

3 Ranki A, Kurki P, Riepponen S, Stephansson E. Antibodies to retroviral proteins in autoimmune connective tissue disease. Arthritis immune connective tissue

4 Olsen R G, Tarr M J,. Mathes L E, et al. Serological and virological evidence of human T-lymphotropic virus in systemic lupus erythematosus. Med Microbiol Immunol (Berl) 1987; 176: 53-64.

5 Brooks S M, Pandolfino Y A, Mitchell T J, et al. The immune response to and expression of cross-reactive retroviral gag sequences in autoimmune disease. Br $\mathcal{F}$ Rheumatol 1992; 31: 735-42.

6 Cohen H, Mackie U, Anagnostopoulos N, Savage G F, Machin S J. Lupus anticoagulant, anticardiolipin antibodies, and human immunodeficiency virus in human immunodeficiency virus in

7 Matsuda J, Gohchi K, Hama H, Tsukamoto M Matsuda J, Gohchi K, Hama H, Tsukamoto $M$
Saitoh N, Kinoshita T. High prevalence of anticardiolipin antibody, Clq-, C3d-, and mRF-IgG immune complexes, and antinuclear antibody in hemophiliacs irrespective of infection with human immunodeficiency virus type 1. F Acquir Immunodefic Syndr 1993 6: $1120-4$.

8 Matsuda J, Saitoh N, Tsukamoto M, Gohchi K, Asami K, Hashimoto M. Measurement of $\beta_{2}$-glycoprotein I (apolipoprotein $\mathrm{H}$ )-independent anticardiolipin antibody in human immunodeficiency virus-1-positive and 43: $146-8$.

9 Exner T, Triplett D A, Taberner D, Machin S J. Guidelines for testing and revised criteria for lupus anticoagulants. SSC subcommittee for the standardization of lupus anticoagulants. Thromb Haemostas 1991; 65: 320-2.

10 Krieg A, Steinberg A D. Retroviruses and autoimmunity. $\mathcal{f}$ Autoimmun 1990; 3: 137-66.

\section{New method for detection of C34-T mutation in the AMPD1 gene causing myoadenylate deaminase deficiency}

Myoadenylate deaminase (MAD) is the muscle isoform of AMP deaminase (EC 3.5.4.6). MAD deficiency is the most common enzyme defect in human skeletal muscle and seems to cause a metabolic myopathy which is found in $2-3 \%$ of all muscle biopsies. ${ }^{1}$ It therefore might be one of the most common causes of exercise-induced myalgias and early fatigue.

MAD is encoded by the AMPD1 gene. Recently, the nonsense mutation C34-T (C-to-T transition at nucleotide 34 in exon 2) in this gene was reported to cause all cases of MAD deficiency studied so far. ${ }^{2}$ This mutation affects the last nucleotide of exon 2 and destroys the MaeII restriction site at the exon 2 - intron 2 boundary. This mutation can therefore be detected by MaeII restriction analysis of the AMPD1 gene after PCR of exon 2 and the adjacent intron sequences. $^{2}$
Studies on small numbers of subjects revealed a frequency of $0 \cdot 119$ of the mutant allele in white populations. ${ }^{2}$ About $1.4 \%$ of the population therefore is assumed to be homozygous for that mutation. Several asymptomatic hymozygotes were identified in these studies. This finding raises questions about the pathogenic significance of MAD deficiency. Determination of allele frequency in larger numbers of subjects with various clinical conditions is required to provide specifics concerning the clinical importance of MAD deficiency. The C34-T mutation which seems to be one of the most common mutations of any gene in white populations is also of ethnological interest since it has not yet been found in the Asian gene pool. $^{2}$

The MaeII restriction analysis faces two major disadvantages: first of all, this enzyme is expensive. Secondly, it is only sufficiently active under specific assay conditions. The reaction sample after PCR cannot be modified to allow the direct digestion with MaeII. Instead, the PCR product must be precipitated and resuspended in the MaeII assay buffer.

Therefore, a new method for detection of the C34-T mutation is presented that is both less expensive and less time consuming. DNA is extracted from blood by standard procedures. Exon 2 and part of intron 2 of the AMPD1 gene are amplified by PCR using two $18 \mathrm{mer}$ primers. The upper primer P1 starts in intron 1 and ends at the second to last nucleotide of exon 2. It corresponds to the wild type AMPD1 gene $^{3}$ with the exception of the second to last nucleotide which is $C$ instead of A (5'-CATACAGCTGAAGAGACA-3'). After amplification of the mutant allele, the PCR product contains the sequence ACATGT at the exon 2 - intron 2 boundary which represents a NspI restriction site. This NspI site is not present after amplification of the wild type allele. The lower primer P2 starts at the 83rd nucleotide of intron 2 (5'-AACACTGCTGAAAAATAG-3'). The PCR product has a size of 119 base pairs. Only the C34-T mutant allele is cut by NspI into two fragments of 20 and 99 base pairs. NspI digestion of heterozygous DNA results in three fragments: two fragments of the mutant allele and one of the unrestricted band of the wild type allele.

The PCR is carried out in a DNA thermal cycler (Perkin Elmer Cetus Instruments) for 30 cycles at $94^{\circ} \mathrm{C}$ denaturing temperature, $44^{\circ} \mathrm{C}$ annealing temperature, and $72^{\circ} \mathrm{C}$ extension temperature, each for one minute. The $100 \mu \mathrm{l}$ PCR reaction volume contains $10 \mathrm{mM}$ Tris- $\mathrm{HCl}, 50 \mathrm{mM} \mathrm{KCl}$, $1.5 \mathrm{mM} \mathrm{MgCl}_{2}, 0.001 \%$ (w/v) gelatine (Perkin Elmer Cetus PCR reaction buffer), $200 \mu \mathrm{M}$ of each dNTP, $150 \mathrm{ng}$ of each primer, 2.5 U AmpliTaq DNA polymerase (Perkin Elmer Cetus) and $10 \mathrm{ng}$ of genomic DNA.

After PCR, $1 / 10$ volume of $100 \mathrm{mM}$ Tris$\mathrm{HCl} \mathrm{pH} \mathrm{7.5,} 100 \mathrm{mM} \mathrm{MgCl}_{2}$ and $10 \mathrm{mM}$ dithiothreitol (L-buffer from USB, Cleveland, Ohio) are added to the reaction volume. The PCR product is mixed with $10 \mathrm{U}$ NspI (USB, Cleveland, Ohio) and . incubated at $37^{\circ} \mathrm{C}$ for one hour. After incubation, the DNA is size separated by electrophoresis in a $2.5 \%$ agarose gel followed by ethidium bromide staining. The 20 base pair fragment is hardly detectable. Only the bands of 99 and 119 base pairs are seen clearly (figure). 


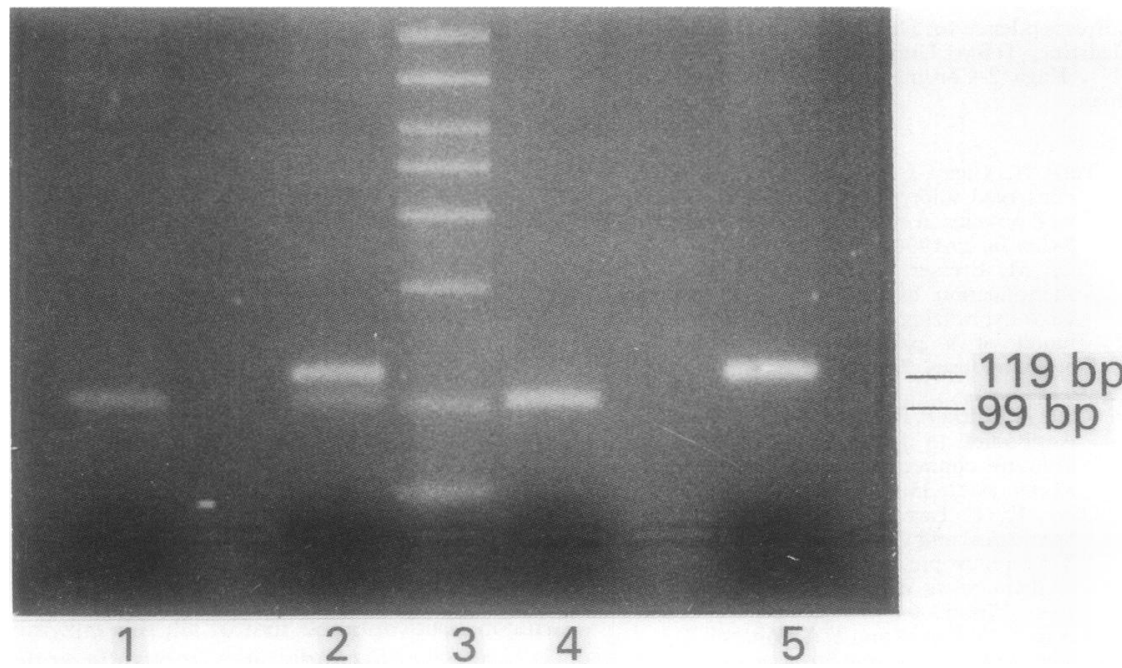

Ethidium bromide staining of an agarose gel after NspI digestion of PCR product. The PCR amplified exon 2 and part of intron 2 of the AMPD1 gene using $P 1$ and $P 2$ primers, $40 \mu$ l of digested $P C R$ product was loaded into a $2 \cdot 5 \%$ gel. $(1,4)$ homozygous patients with $M A D$ deficiency; (2) heterozygous mother of patient (1); (3) PCR size marker with band of 50, 100, 200, 300, 400, 500, 700 and $1000 \mathrm{bp}$; (5) wild type DNA.
DNA of 11 patients with MAD deficiency ${ }^{2}$ and 100 randomly selected subjects were analysed for the C34-T mutation using both methods and always demonstrated identical results. The mismatch in primer 1 did not prevent sufficient PCR amplification in any experiment.

M GROSS

Medizinische Poliklinik, University of Munich University of Munich,
Pettenkoferstraße $8 a$ Pettenkoferstraße $8 a$,
80336 München, Germany

1 Sabina R L, Swain J L, Holmes E W. Myoadenylate deaminase deficiency. In: Scriver C R, Beaudet A L, Sly W S, Valle D eds. The metabolic basis of inherited disease, 6th ed. New York: McGraw-Hill, 1989 1077-84.

2 Morisaki T, Gross M, Morisaki H, Pongratz D, Zöllner N, Holmes E W. Molecular basis of AMP deaminase deficiency in skeletal muscle. Proc Natl Acad Sci USA 1992; 89: 6457-61.

3 Sabina $\mathrm{R}$ L, Morisaki $\mathrm{T}$, Clarke $\mathrm{P}$, et al Characterization of the human and rat myoadenylate deaminase genes. $\mathcal{f}$ Biol Chem 1990; 265: 9423-33. 